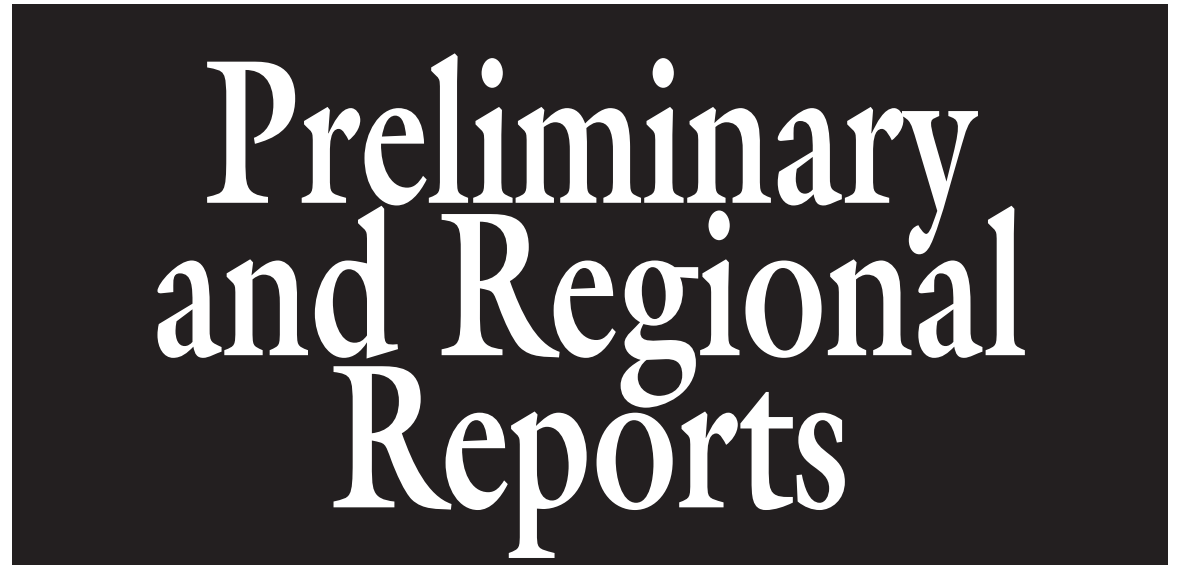

\section{Evaluation of 'AU-Performance' Watermelon for Its Response to Virus Inoculation}

\author{
John F. Murphy ${ }^{1,3}$ and Fenny Dane ${ }^{2}$
}

ADDITIONAL INDEX WORDS. PRSV, WMV, ZYMV, potyvirus

Summary. The watermelon (Citvullus lanatus var. lanatus) 'AU-Performance' was developed for resistance to multiple fungal pathogens and the plant virus, zucchini yellow mosaic virus (ZYMV). A greenhouse-based evaluation was carried out to determine the response of 'AU-Performance' to inoculation with three important cucurbit (Cucurbitaceae) viruses in the genus Potyvirus: papaya ringspot virus (PRSV), watermelon mosaic virus (WMV), and ZYMV. The evaluation included the resistant parent (PI595203), the susceptible parent ('AU-Producer'), and varieties AU-Allsweet and Charleston Gray. Each of the three viruses systemically infected 'AU-Performance' with $100 \%$ infection and development of characteristic systemic symptoms. The susceptible parent ('AU-Producer'), 'AU-Allsweet', and

'Charleston Gray' responded similarly with $100 \%$ infection and systemic symptoms. In contrast, the resistant parent (PI595203) was resistant to WMV and ZYMV; however, PRSV-inoculated plants developed a systemic infection with accompanied symptoms and high levels of PRSV accumulation in noninoculated leaves. PI595203 was shown in previous studies to be resistant to PRSV. We show in this report that under greenhouse conditions and application of virus by mechanical inoculation, 'AU-Performance' was not resistant to infection by the three potyviruses.

$\mathrm{P}$ lant viruses are extremely difficult to manage in vegetable crops, particularly those viruses transmitted by aphids (Aphididae) in a nonpersistent manner. Viruses in the genus Potyvirus [e.g., papaya ringspot virus (PRSV), watermelon mosaic virus (WMV), and zucchini yellow mosaic virus (ZYMV)] are transmitted by aphids in a nonpersistent manner and are considered a constant threat to cucurbit crops (Guner and Wehner, 2008; Zitter et al., 1996). Efforts to reduce losses caused by these viruses by application

${ }^{1}$ Department of Entomology and Plant Pathology, 209 Life Sciences Building, Auburn University, Auburn, AL 36849

${ }^{2}$ Department of Horticulture, 201 Funchess Hall, Auburn University, Auburn, AL 36849

${ }^{3}$ Corresponding author. E-mail: murphjf@auburn.edu. of insecticides to control their aphid vectors typically are not effective because of their rapid acquisition from a source plant and subsequent transmission to a healthy plant (Hull, 2002). Moreover, insecticides may increase aphid activity, thereby increasing plant-to-plant spread of the virus (Raccah, 1986).

Cultural practices, such as use of ultraviolet-reflective mulches and interrow soil covers, have been effective means to reduce virus incidence in cucurbit crops (Chalfant et al., 1977; Damicone et al., 2007; DiazPerez et al., 2003; Murphy et al., 2009; Murphy et al., 2008; Summers et al., 1995; Toba et al., 1977). The most effective means of protection against virus infection, however, is host resistance. The availability of genetically resistant plant varieties reduces or eliminates concerns about virus vectors and requires little, if any, input from the grower.

Provvidenti (1991) evaluated 57 PIs and 11 commercial varieties of watermelon for resistance to three strains of ZYMV. Only four of the PIs were resistant to ZYMV and the resistance was inherited as a single recessive gene designated zym. Boyhan et al. (1992) evaluated 153 PIs, breeding lines, and commercial varieties for resistance to the Florida strain of ZYMV (ZYMV-FL). They identified five sources of resistance, and included among them was PI595203 (also referred to as 'Egun'). Gillaspie and Wright (1993) stated that "the term Egun is probably Egusi miswritten or misspelled" and showed that PI595203 was a strong source of resistance to WMV. PI595203 was later shown to be resistant to the watermelon strain of PRSV (Strange et al., 2002) and Chinese strains of WMV and ZYMV (Xu et al., 2004). A single recessive gene in PI595203 conferred resistance to the watermelon strain of PRSV (Guner and Wehner, 2008) and the Chinese strain of ZYMV (Xu et al., 2004), whereas at least two recessive genes were associated with resistance to WMV (Xu et al., 2004).

The watermelon variety AUProducer was developed for multiple fungal disease resistance [anthracnose (Colletotrichum obiculare) and gummy stem blight (Didymella bryoniae)] adapted to the growing conditions of the southeastern United States by J.D. Norton. The discovery of ZYMV resistance in 'Egun' (Boyhan et al., 1992 ) led to the continuation of breeding efforts to introgress the ZYMV resistance of PI595203 ('Egun') into

\begin{tabular}{llll}
\hline $\begin{array}{l}\text { Units } \\
\text { Units To convert U.S. to SI, } \\
\text { multiply by }\end{array}$ & U.S. unit & SI unit & $\begin{array}{l}\text { To convert SI to U.S., } \\
\text { multiply by }\end{array}$ \\
\hline 29.5735 & $\mathrm{fl} \mathrm{oz}$ & $\mathrm{mL}$ & 0.0338 \\
28.3495 & $\mathrm{OZ}$ & $\mathrm{g}$ & 0.0353 \\
$\left({ }^{\circ} \mathrm{F}-32\right) \div 1.8$ & ${ }^{\circ} \mathrm{F}$ & ${ }^{\circ} \mathrm{C}$ & $\left(1.8 \times{ }^{\circ} \mathrm{C}\right)+32$
\end{tabular}

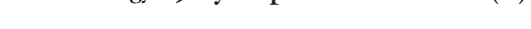


'AU-Producer'. A cross between PI595203 and 'AU-Producer' was used, followed by four backcross generations and field selections for diseaseresistant seedlings that produced high yields of excellent fruit quality (Boyhan et al., 2001, 2002, 2000). The resulting variety was tentatively named AUPerformance.

In the current study, we evaluated two seedlots of 'AU-Performance' plants for their response to inoculation with PRSV, WMV, and ZYMV. A comparative evaluation included the resistant parent (PI595203), the susceptible parent ('AU-Producer'), and two additional varieties, AU-Allsweet (Auburn University) and Charleston Gray.

\section{Materials and methods}

Experiments were performed at the Auburn University Plant Science Facility in Auburn, AL. The watermelon genotypes included two seedlots of 'AU-Performance' (seedlot 1 and 2), the resistant parent [PI595203 (provided by T.C. Wehner; originally obtained from the Plant Genetic Resources Conservation Unit, Griffin, GA)], the susceptible parent ('AU-Producer') and two additional susceptible varieties, AU-Allsweet and Charleston Gray (Reimers Seeds, Mount Holly, NC). 'AU-Performance' was initially referred to as 'AU-Producer-ZYMV' in variety trials conducted in Georgia. Seeds of each genotype were sown on 21 Apr. 2008 in soilless potting medium (Pro-Mix; Premier Peat, Riviére-du-Loup, QU, Canada) in Styrofoam trays (72 wells per tray; Speedling, Busnell, FL). Upon germination, seedlings were transplanted to $15-\mathrm{cm}$-diameter round pots containing Pro-Mix (transplanted on 30 Apr.). Plants were arranged in virusspecific blocks. Each block consisted of each genotype in randomly arranged rows of five plants with three replicates ( 15 plants of each genotype in each virus block). A single row of five plants of each genotype served as a mock-inoculated control and was arranged within each virus block.

The response of PI595203 to inoculation with each virus was tested further in a separate experiment. Each virus treatment consisted of randomly arranged rows of five plants with three replications (15 plants inoculated with each virus). There was a single row of five plants that served as a mock-inoculated control.

Watermelon seedlings were inoculated with PRSV (Florida strain), WMV (Alabama isolate, collected from infected pumpkin at the EV Smith Agricultural Experiment Station, Shorter, AL), or ZYMV (Florida strain). PRSV and ZYMV were purchased from the American Type Culture Collection (Rockville, MD). Virus inoculum consisted of systemically infected 'Dixie' squash (Cucurbita pepo var. melopepo) leaves ground in $15 \mathrm{~mL}$ of $50 \mathrm{~mm}$ potassium phosphate buffer, $\mathrm{pH} \mathrm{7.3,} \mathrm{containing} 10 \mathrm{~mm}$ sodium sulfite. Inoculum was applied by rub-inoculation using inoculumsaturated cheesecloth. All mortars and pestles and buffer were chilled before use and were maintained on ice during the inoculation procedure. At the time of inoculation, seedlings were at the one-true leaf stage and virus was applied to cotyledons and the first true leaf.

Plants were monitored for the development of virus symptoms throughout the course of the experiment. A single leaf sample was collected from each plant (the second or third leaf from the stem tip) at 10 and $20 \mathrm{~d}$ postinoculation (DPI) and was tested for the presence of virus using a commercial ELISA kit specific to the respective virus (Agdia, Elkhart, IN). The ELISA procedure was performed as recommended by the manufacturer with a few modifications. The primary antibody (coating step) and sample incubation steps were kept in a moist chamber for at least $12 \mathrm{~h}$ at $4{ }^{\circ} \mathrm{C}$. The secondary antibody step (conjugated antibody) was incubated in a moist chamber at $37^{\circ} \mathrm{C}$ for 2 to $3 \mathrm{~h}$. Leaf samples were processed using a motorized leaf squeezing apparatus with the addition of general extraction buffer (as described by the manufacturer) at a ratio of $\mathrm{lg}$ of tissue to $5 \mathrm{~mL}$ of buffer. Leaf extracts were added to microtiter plates at a final dilution of 1:25 (tissue:buffer). After adding substrate, reactions were allowed to develop at room temperature for 15 to $30 \mathrm{~min}$ and were then recorded using a Sunrise microtiter plate reader (Phenix Research Products, Hayward, CA). A sample was considered positive for the presence of virus if the ELISA absorbance value was greater than the healthy control threshold. The healthy control threshold was determined from the average ELISA absorbance value plus three standard deviations of three negative control samples that were included on each microtiter plate.

In the additional experiment to further test PI595203, an inoculated cotyledon and the inoculated first true leaf were each tested, separately, for virus infection at 10 DPI. Virus detection was as described above using the respective virus-specific ELISA kit (Agdia).

\section{Results and discussion}

RESPONSE OF 'AU-PERFORMANCE' TO POTYVIRUS INOCULATION. 'AU-Performance' plants (seedlots I and 2) were susceptible to each of the potyviruses. A $100 \%$ infection incidence occurred at 10 and 20 DPI for PRSV, WMV, and ZYMV (Table 1). Each of the potyviruses induced systemic symptoms consisting of various forms of mosaic patterns on leaves, leaf deformation, and shortening of vines. Average ELISA values indicated that each virus accumulated to relatively high levels in noninoculated leaves (i.e., those leaves representing systemic infection) at 10 and 20 DPI (Table 1). PRSV and ZYMV accumulation, based on ELISA values, increased in systemically infected leaf tissues from 10 to 20 DPI, whereas WMV accumulation decreased from 10 to 20 DPI.

RESPONSE OF PI595203 TO POTYVIRUS INOCULATION. PI595203 plants inoculated with WMV did not develop symptoms and virus was not detected in noninoculated leaves throughout the course of the experiment (Table 1). In contrast, all PRSVinoculated plants developed a systemic infection by 10 DPI with continued expression of infection at 20 DPI (Table 1). PRSV-induced symptoms consisted of a systemic mosaic on leaves with general stunting of vines relative to mock-inoculated control plants. PRSV accumulated to relatively high levels in noninoculated leaves at 10 and 20 DPI when tested by ELISA (Table 1). Twenty-eight percent of ZYMV-inoculated PI595203 plants were infected at 10 and 20 DPI (Table 1). Average ELISA values were positive for ZYMV infection at both testing dates, although they were relatively low due to inclusion of samples that were negative and 
positive for ZYMV infection in the average ELISA values (Table 1). For those plants that were infected with ZYMV, a mild chlorotic mosaic occurred on a few leaves, and the average ELISA value for these plants was 1.005 and 1.232 at 10 and 20 DPI, respectively.

The strong level of resistance to systemic infection (symptoms and detection of virus in noninoculated leaves by ELISA) expressed by PI595203 plants was tested further by examination of virus accumulation in inoculated cotyledons and leaves. As observed in previous tests, PI595203 plants were susceptible to infection by PRSV with $100 \%$ infection of inoculated cotyledons and leaves with accompanied high levels of virus accumulation (Table 2). In contrast to tests for systemic infection, WMV infection was detected in $75 \%$ of inoculated leaves, although in only $33 \%$ of inoculated cotyledons. Similarly, ZYMV infection occurred in more inoculated leaves $(58 \%)$ than inoculated cotyledons (8\%) (Table 2). For WMV and ZYMV, average ELISA values were positive but low, a reflection of the low incidence of infection.

Response of 'AU-PRODUCER', 'CHARLESTON GRAY', AND 'AUALLSWEET' TO POTYVIRUS INOCULATION. The varieties AU-Producer,
Charleston Gray, and AU-Allsweet were susceptible to infection by PRSV, WMV, and ZYMV. In each case, $100 \%$ of the inoculated plants were systemically infected by the respective virus at 10 and 20 DPI (Table 1) along with production of systemic mosaic symptoms in leaves on all developing vines. ELISA tests indicated that each virus accumulated to relatively high levels in noninoculated leaves at 10 and 20 DPI (Table 1).

'AU-Performance' was developed as an improved version of 'AUProducer' with fungal and ZYMV resistance. The resistant parent of 'AU-Performance', PI595203, was shown to be resistant to PRSV,

Table 1. Percentage of virus infection and average ELISA value for watermelon genotypes inoculated with plant potyviruses.

\begin{tabular}{|c|c|c|c|c|c|c|}
\hline \multirow[b]{2}{*}{ Genotype } & \multicolumn{2}{|c|}{ PRSV $^{z}$} & \multicolumn{2}{|c|}{ WMV } & \multicolumn{2}{|c|}{ ZYMV } \\
\hline & $10 \mathrm{DPI}^{\mathrm{y}}$ & 20 DPI $^{y}$ & $10 \mathrm{DPI}$ & $20 \mathrm{DPI}$ & 10 DPI & 20 DPI \\
\hline \multicolumn{7}{|c|}{ 'AU-Performance' (seed lot 1 ) } \\
\hline ELISA $($ mean \pm SD $)$ & $0.918 \pm 0.33^{\mathrm{w}}$ & $1.392 \pm 0.26$ & $0.918 \pm 0.13$ & $0.397 \pm 0.09$ & $0.682 \pm 0.08$ & $1.402 \pm 0.23$ \\
\hline \multicolumn{7}{|c|}{ 'AU-Performance' (seed lot 2) } \\
\hline Infection $(\%)$ & 100 & 100 & 100 & 100 & 100 & 100 \\
\hline Infection $(\%)$ & 100 & 100 & 0 & 0 & 28 & 28 \\
\hline ELISA $($ mean $\pm \mathrm{SD})$ & $1.007 \pm 0.26$ & $1.150 \pm 0.31$ & $0.146 \pm 0.01^{\mathrm{v}}$ & $0.078 \pm 0.0 \mathrm{I}^{\mathrm{v}}$ & $0.367 \pm 0.42$ & $0.421 \pm 0.53$ \\
\hline \multicolumn{7}{|l|}{ 'AU-Producer' } \\
\hline Infection $(\%)$ & 100 & 100 & 100 & 100 & 100 & 100 \\
\hline ELISA $($ mean $\pm \mathrm{SD})$ & $1.028 \pm 0.33$ & $1.434 \pm 0.23$ & $0.701 \pm 0.14$ & $0.400 \pm 0.06$ & $0.711 \pm 0.11$ & $1.585 \pm 0.18$ \\
\hline \multicolumn{7}{|l|}{ 'Charleston Gray' } \\
\hline Infection $(\%)$ & 100 & 100 & 100 & 100 & 100 & 100 \\
\hline ELISA $($ mean \pm SD $)$ & $1.170 \pm 0.41$ & $1.327 \pm 0.18$ & $0.854 \pm 0.17$ & $0.472 \pm 0.09$ & $0.794 \pm 0.15$ & $1.511 \pm 0.20$ \\
\hline
\end{tabular}

${ }^{2} \mathrm{PRSV}=$ papaya ringspot virus, $\mathrm{WMV}=$ watermelon mosaic virus, $\mathrm{ZYMV}=$ zucchini vellow mosaic virus.

${ }^{y}$ Leaf samples (noninoculated, young leaves) were collected from each plant at 10 and $20 \mathrm{~d}$ postinoculation (DPI).

xercentage of infection was determined from the number of plants infected/the number of plants in the respective treatment. Virus infection was based on the occurrence of virus symptoms and the detection of virus in leaf samples by ELISA.

"Average ELISA \pm SD for leaf samples in the respective treatment. The threshold for a positive average ELISA value was determined from the average plus 3 SD for healthy control samples of each watermelon genotype. Threshold values were 0.159 and 0.076 for PRSV, 0.231 and 0.155 for WMV, and 0.253 and 0.218 for ZYMV at 10 and 20 DPI, respectively.

"Average ELISA not above the healthy control threshold and therefore not considered positive for virus infection.

Table 2. Average ELISA value and percentage of virus infection in the inoculated cotyledon and leaf of PI595203 watermelon.

\begin{tabular}{|c|c|c|c|c|c|c|}
\hline \multirow[b]{2}{*}{ Evaluation } & \multicolumn{2}{|c|}{$\mathrm{PRSV}^{\mathrm{z}}$} & \multicolumn{2}{|c|}{$\mathrm{WMV}^{\mathrm{z}}$} & \multicolumn{2}{|c|}{$\mathrm{ZYMV}^{\mathrm{z}}$} \\
\hline & $\operatorname{Cot}^{\mathrm{y}}$ & $\operatorname{Lf} 1^{y}$ & Cot & Lf 1 & Cot & Lf 1 \\
\hline Infection (\%) & $100^{x}$ & 100 & 33 & 75 & 8 & 58 \\
\hline
\end{tabular}

${ }^{\mathrm{z}} \mathrm{PRSV}=$ papaya ringspot virus, WMV = watermelon mosaic virus, ZYMV = zucchini yellow mosaic virus.

'Tested samples included one inoculated cotyledon (Cot) and inoculated leaf 1 (Lf 1 ).

'Percentage of infection was determined from the number of samples that tested positive for infection/the total number of samples in the respective treatment. Infection was based on the occurrence of virus-induced symptoms and the detection of virus by ELISA.

wAverage ELISA for the respective treatment from samples collected at $10 \mathrm{~d}$ postinoculation. The threshold for a positive average ELISA value was determined from the average plus 3 SD for healthy control samples of watermelon genotype PI595203. Threshold values were 0.076 for PRSV, 0.080 for WMV, and 0.082 for ZYMV for cotyledon and leaf samples. 
WMV, and ZYMV (Boyhan et al., 1992; Gillaspie and Wright, 1993; Strange et al., 2002; Xu et al., 2004). Our data show that 'AU-Performance' is not resistant to PRSV, WMV, or ZYMV. These results suggest that the recessive resistance of PI595203 to ZYMV was not introgressed into 'AU-Producer'.

Our results describing the resistance of PI595203 to WMV and ZYMV corroborate those of Boyhan et al. (1992) and Xu et al. (2004). However, we did not detect resistance to PRSV as reported by Strange et al. (2002) even though the Florida strain of PRSV was used on both studies. The reason for these differences was not determined.

Examination of virus accumulation in inoculated cotyledons and leaves revealed a degree of susceptibility to WMV not observed in noninoculated leaves. This indicates that WMV was able to infect and move within some inoculated leaves, but was unable to establish a systemic infection. This type of resistance where virus is limited or restricted in its ability to move within the plant is not uncommon (Choi et al., 2003; Thompson and Garcia-Arenal, 1998; Wong et al., 1999), although further investigation into the mechanism of the resistance expressed by PI595203 would be highly useful for future breeding programs.

\section{Literature cited}

Boyhan, G., J.D. Norton, B.J. Jacobsen, and B.R. Abrahams. 1992. Evaluation of watermelon and related germplasm for resistance to zucchini yellow mosaic virus. Plant Dis. 76:251-252.

Boyhan, G.E., D.B. Langston, D.G. Riley, D.M. Granberry, C.R. Hill, D.E. Curry, and R.L. Torrance. 2000. Evaluation of watermelon and cantaloupe varieties. Georgia Veg. Ext. Res. Rpt. 2000: $15-20$.
Boyhan, G.E., D.M. Granberry, W.T. Kelly, and C.R. Hill. 2001. Watermelon variety trial 2001. Georgia Veg. Ext. Res. Rpt. 2001:21-23.

Boyhan, G.E., D.M. Granberry, W.T. Kelly, K.L. Lewis, W.T. Jennings, J.K. Phillips, and C.R. Hill. 2002. Watermelon and cantaloupe variety trials. Georgia Veg. Ext. Res. Rpt. 2002:48-55.

Chalfant, R.B., C.A. Jaworski, A.W. Johnson, and D.R. Sumner. 1977. Reflective film mulches, millet barriers, and pesticides: Effects on watermelon mosaic virus, insects, nematodes, soil-borne fungi, and yield of yellow summer squash. J. Amer. Soc. Hort. Sci. 102:11-15.

Choi, S.K., J.K. Choi, and K.H. Ryu. 2003. Involvement of RNA2 for systemic infection of Cucumber mosaic virus isolated from lily on zucchini squash. Virus Res. 97:1-6.

Damicone, J.P., J.V. Edelson, J.L. Sherwood, L.D. Meyers, and J.E. Motes. 2007. Effects of border crops and intercrops on control of cucurbit virus diseases. Plant Dis. 91:509-516.

Diaz-Perez, J.C., K.D. Batal, D. Granberry, D. Bertrand, and D. Giddings. 2003. Growth and yield of tomato on plastic film mulches as affected by tomato spotted wilt virus. HortScience 38:395399.

Gillaspie, A.G. and J.M. Wright. 1993. Evaluation of Citrullus sp. germplasm for resistance to watermelon mosaic virus 2 . Plant Dis. 77:352-354.

Guner, N. and T.C. Wehner. 2008. Overview of potyvirus resistance in watermelon, p. 445-451. Proc. IXth EUCARPIA Meeting Cucurbitaceae, Avignon, France.

Hull, R. 2002. Matthew's plant virology, 4th ed. Academic Press, New York.

Murphy, J.F., J. Mosjidis, M.D. Eubanks, and J. Masiri. 2008. Inter-row cover crops to reduce incidence of aphid-borne viruses in pumpkin. Intl. J. Veg. Sci. 14: 209-303.

Murphy, J.F., M.D. Eubanks, and J. Masiri. 2009. Reflective plastic mulch but not a resistance-inducing treatment reduced Watermelon mosaic virus incidence and yield losses in squash. Intl. J. Veg. Sci. 15:3-12.

Provvidenti, R. 1991. Inheritance of resistance to the Florida strain of zucchini yellow mosaic virus in watermelon. HortScience 26:407-408.

Raccah, B. 1986. Nonpersistent viruses: Epidemiology and control. Adv. Virus Res. 31:387-428.

Strange, E.B., N. Guner, Z. Pesic-VanEsbroeck, and T.C. Wehner. 2002. Screening the watermelon germplasm collection for resistance to papaya ringspot virus type W. Crop Sci. 42:1324-1330.

Summers, C.G., J.J. Stapleton, A.S. Newton, R.A. Duncan, and D. Hart. 1995. Comparison of sprayable and film mulches in delaying the onset of aphidtransmitted virus diseases in zucchini squash. Plant Dis. 79:1126-1131.

Thompson, J.R. and F. Garcia-Arenal. 1998. The bundle sheath-phloem interface of Cucumis satious is a boundary to systemic infection by tomato aspermy virus. Mol. Plant Microbe Interact. 11: 109-114.

Toba, H.H., A.N. Kishaba, G.W. Bohn, and H. Hield. 1977. Protecting muskmelon against aphid-borne viruses. Phytopatholology 67:1418-1423.

Wong, S.M., S.S.C. Thio, M.H. Shintaku, and P. Palukaitis. 1999. The rate of cellto-cell movement in squash of cucumber mosaic virus is affected by sequences in the capsid protein. Mol. Plant Microbe Interact. 12:628-632.

Xu, Y., D. Kang, Z. Shi, H. Shen, and T. Wehner. 2004. Inheritance of resistance to zucchini yellow mosaic virus and watermelon mosaic virus in watermelon. J. Hered. 95:498-502.

Zitter, T.A., D.L. Hopkins, and C.E. Thomas. 1996. Compendium of cucurbit diseases. APS Press, St. Paul, MN. 